\title{
Does Audit Committee Reduce Earnings Management in Banks? Evidence from Tunisian Context
}

\author{
Amina Zgarni ${ }^{1} \&$ Hassouna Fedhila ${ }^{2}$ \\ ${ }^{1}$ Faculty of Economic Sciences and Management of Tunis, University of Tunis El Manar, Tunisia \\ ${ }^{2}$ The Higher Institute of Accounting and Business Administration, University of Mannouba, Tunisia \\ Correspondence: Amina Zgarni, Faculty of Economic Sciences and Management of Tunis, Tunisia. E-mail: \\ amina2302@yahoo.fr
}

Received: June 14, 2019

Accepted: July 11, 2019

Online Published: July 29, 2019

doi:10.5539/ass.v15n8p86

URL: https://doi.org/10.5539/ass.v15n8p86

\begin{abstract}
In the business world, financial information disseminated by companies reveals an undeniable importance, and this is an unavoidable necessity for any decision- making of the various stakeholders (investors, lenders, customers, employees, public authorities, etc.). This study aims to determine the nature of the impact of the introduction of an audit committee on the financial reporting quality, in particular the earnings management, in the banking context. Through the static panel method and a sample of all Tunisian commercial banks, over a period from 2001 to 2014, the study shows, surprisingly, that the audit committee is a catalyst for earnings management.
\end{abstract}

Keywords: audit committee, financial reporting quality, earnings management

Classification JEL: G14, M4, M41

\section{Introduction}

In the business world, the financial information disseminated by companies reveals an undeniable importance, and this is an unavoidable necessity for any decision-making of the various stakeholders (Investors, lenders, customers, employees, public authorities, etc.). In this regard, Bushman and Smith $(2001,2003)$ point out that financial information is the basis for the capital market participants' investment decision. It is concomitantly useful for business owners and regulators and assistants to determine the company's past performance predict its future and control the actions of managers. However, the reality is far from this idyllic scheme. The multiplications of financial crises, spectacular bankruptcies and financial and economic scandals that have ravaged most of the world's economies have cast doubt on the financial reporting quality disclosed. In fact, managers are constantly manipulating accounting information thanks to the room for maneuver they hold without distorting regulation, for reasons that do not include reducing financing costs and maximizing their wealth. In this regard, Brown (2011) reveals that the accounting scandals that have occurred in the international financial communities have increased the criticism of the financial reporting quality. Watts and Zimmerman $(1986,1990)$ explain that it is the flexibility of the rules that allows managers to exercise judgment in publishing earnings based on discretionary objectives. Carassus and Cormier (2003), for their part, support the idea that the existence of accounting manipulations, through the earnings management, questioned the question of the trust in the financial reporting quality disclosed, in particular the earnings quality.

Thus, recently, an immense literature and many researches arise on the earnings management and its impact on the financial reporting quality disclosed by the banks. In addition, according to Macey and O'Hara (2003), the specificities of the banking sector and the importance of the asymmetry of information and governance persist. As a result, the establishment of external but also internal governance mechanisms is a priority for banks. The main purpose of these monitoring mechanisms, control the activity of the managers and limit his opportunistic behavior.

It is in this context that the introduction of an audit committee in each type of companies has become indispensable. The SOX Act 2002 and the 8th European Directive, which aims to improve the governance of companies and banks, strengthens the role and the authority of audit committee.

The objective of this document would then be to detect the effect of the audit committee's presence on the quality 
of financial information, particularly on earnings management in banks.

For that, this paper will be organized as follows. The second section is devoted to the literature review and hypotheses development. The third section is reserved for the research methodology. In the fourth section, the empirical results are presented and in the last section we present the conclusion.

\section{Literature Review and Hypotheses Development}

Studies on the effect of governance mechanisms, particularly the audit committee, on the quality of disclosed financial information are becoming increasingly important, particularly in the wake of financial crises and scandals that have disrupted most world economies over the past two decades.

An in-depth review of the empirical research conducted by Piot and Kermiche (2009) admits the divergence of the results of work on this topic. In this context, Mazzola et al. (2011) show that the role of the audit committee is fundamental and effective in reducing earnings management after the introduction of IFRS. McMullen (1996) has previously demonstrated that the existence of the audit committee reduces the frequency of errors and irregularities in the financial statements. Uzun et al. (2004) validate this fact, confirming that the presence of the audit committee prevents fraud and limits the opportunistic management of results.

In Australia, Davidson et al. (2005), certify through their empirical study that the presence of an audit committee reduces the propensity to publish a low-growth result, a practice that presupposes the opportunistic management of accounting figures. For their part, Jaggi and Leung (2007) attest that the presence of an audit committee within a company can limit earning management. Similarly, in Hong Kong, where most businesses are concentrated and often owned by families, Jaggi and Leung (2007) argue that the presence of the audit committee prevents fraud. Baxter and Cotter (2009) also prove, in the Australian context, that the presence of an audit committee has a disciplinary effect translating by the reduction of earning management.

For banks, it is important to note that studies on the audit committee's impact on earning management are very limited. In this context, in a sample of Islamic banks in the Middle East, Ben Othman and Mersni (2016) confirm the role of the audit committee in limiting the discretionary behavior of managers. Similarly, by studying the impact of the audit committee on discretionary practices in a sample of Nigerian and Malaysian banks over a period from 2007 to 2011, Ahmed et al. (2013) found that this mechanism limited the opportunistic behavior of managers of these banks.

However, Menon and Williams (1994) demonstrate that the mere existence of the audit committee is not necessarily equivalent to effectiveness and the fact that the board relies on this committee to improve its ability to control. On their part, Peasnell et al. (2000) showed that there was no significant relationship between the audit committee and the earning management in a sample of UK companies. From the same perspective, Davidson et al. (2005) found in their first model a non-significant relationship between the audit committee and earning management.

For its part, Alves (2013), from a sample of 33 non-financial corporations established in Portugal over a period from 2003 to 2009, asserts that the existence of the audit committee only accentuates the problem of earning management. More recently, Chen et al. (2015) wondering whether Japanese companies adopting audit committees could improve the quality of results. They showed that improving the quality of earnings cannot be achieved simply by setting up an audit committee. These authors indicate that many Japanese companies can adopt the audit committee as a fashionable "label" without protecting shareholder interests.

Thus, just as Davidson et al. (2005), Jaggi and Leung (2007), and Ben Othman and Mersni (2016), we expect, in this research, a negative association between the presence of the audit committee and the earning management in Tunisian banks.

From the above developments, we then put the following hypothesis:

The presence of an audit committee has a negative impact on discretionary loan loss provisions in Tunisian commercial banks.

\section{Research Methodology}

\subsection{Sample and Data}

To test our hypothesis, we used a sample of all Tunisian commercial banks. The analysis period ranges from 2001 to 2014. That is 140 observations.

\subsection{Variables Measurement}

- Dependents variables 
*LLP: Total loan loss provisions for bank i in year t divided by total loans in year t-1.

*DLLP: discretionary loan loss provisions of Bank i in year $t$ divided by total loans in year $t-1$ : measured by the following equation: LLPit - NDLLPit

With:

NDLLPit: Non-discretionary loan loss provisions of bank i to year $t$ divided by total loans in year t-1

In fact, we will use three variables to calculate non-discretionary loan loss provisions, namely: non-performing loans (NPL), the variation of non-performing loans ( $\triangle \mathrm{NPL})$, and the variation of loans $(\triangle \mathrm{LOAN})$

\section{- Interest variable: presence of audit committee (COM)}

LikeBeasley(1996), Dechow etal(1996), Jaggi and Leung(2007), Janin and Piot(2008) and Ben Othmen and Mersni (2016), we will measure audit committee' existence (COM) by a dichotomous variable which takes the value 1 if there is an audit committee within the bank and 0 otherwise.

\section{- Control variables}

*The accounting performance of bank (ROA):

In the manner of Kothari et al. (2005), we measure the accounting performance by the return on assets (ROA), which is used as an additional indicator associated with business risks.

*The bank size (LASSET)

In this work, we will use the natural logarithm of the total assets of the firm as a measure of the size of the bank (Kanagaretnam et al., 2004).

*Audit quality (BIG)

In our study, we will measure the audit quality by a dichotomous variable that takes the value 1 if the external auditor belongs to the group BIG 4 and 0 otherwise. In fact, according to Pittman and Fortin (2004), belonging to auditors (Big4), improves the quality of accounting disclosure of companies, reduces information asymmetry and uncertainty partnersofthe company, as wellastheopportunistic behaviorofthemanagers (Peasnell et al., 2005).

*The bank age (AGE)

The bank age is also expected to help reduce earnings management because of the experience gained by the bank's management. We propose to measure this variable by the logarithm of the number of years of exercise of the firm (Ben Cheikh \& Zarai, 2008).

\subsection{Models Estimation}

The objective of this study is to identify the impact of the mere existence of the Audit Committee on earnings management in Tunisian commercial banks. To do this, we will follow two steps. In fact, our approach is identical to of Kanargaretnam et al. (2004)

- The firstmodel:

First at all, it is very useful to point out that the ultimate objective of this first model is to determine the level of discretionary provisions within Tunisian banks.

The loan loss provisions are thus broken down into two parts: the first part reflects the normal or non-discretionary component (NDLLP) assumed to be influenced by the provision policy in banks and the second part represents the residual part (the discretionary component of this variable: DLLP).

Equation (1) represents the first model to estimate:

$$
L L P_{i t}=\propto_{0}+\propto_{1} N P L_{i t}+\propto_{2} \Delta N P L_{i t}+\propto_{3} \Delta L O A N_{i t}+\varepsilon_{i t}
$$

The estimate of equation 1 gives us the non-discretionary loan loss provisions:

$$
N D L L P_{i t}=\widehat{\alpha}_{0}+\widehat{\alpha}_{1} N P L_{i t}+\widehat{\alpha}_{2} \Delta N P L_{i t}+\widehat{\alpha}_{3} \Delta L O A N_{i t}
$$

Thus:

- The second model:

$$
D L L P_{i t}=L L P_{i t}-N D L L P_{i t}=\widehat{\varepsilon}_{i t}
$$

Using the discretionary provisions calculated following the estimation of the first model above, we proceed with the regression of the audit committee variable and other control variables to test their effect on the discretionary provisions. 
Thus, for this second model: the variable of interest is "the presence of the audit committee" (COM) and the control variablesare: thereturnonassets(ROA), thesizeofthebank(LASSET), thequality ofthe audit (BIG) and the age of the bank (AGE).

Hence, following model that will allow us to verify our research hypotheses. This model is inspired by Alves (2013).

$$
D L L P_{i t}=\propto_{0}+\propto_{1} \operatorname{COM}_{i t}+\propto_{2} R O A_{i t}+\propto_{3} \operatorname{LASSET}_{i t}+\propto_{4} A G E_{i t}+\varepsilon_{i t}
$$

\section{Results andDiscussion}

\subsection{Descriptive Statistics}

The Table 1 presents the descriptive statistics of the variables used in this research work:

Table 1. Descriptive statistics of the variables of the study

\begin{tabular}{cccccc}
\hline Variable & Mean & Minimum & Maximum & Standard deviation & Observation \\
\hline DLLP & $-6.96 \mathrm{e}-12$ & -.0329875 & .1301552 & .0257245 & 140 \\
COM & .8285714 & 0 & 1 & .3782363 & 140 \\
ROA & .0078196 & -.0882665 & .031 & .0112917 & 140 \\
LASSET & 14.98996 & 13.81444 & 15.99403 & .5575623 & 140 \\
BIG & .5214286 & 0 & 1 & .5013343 & 140 \\
AGE & 3.617714 & .3022093 & 2.639057 & 4.043051 & 140 \\
\hline
\end{tabular}

DLLP: discretionary loan loss provisions; COM: presence of audit committee, ROA: return on assets; LASSET: size of bank; BIG: the belonging of external auditor to the Big 4 group, AGE: age of the bank

Thus, the results show that, on average, in the Tunisian commercial banks that are the subject of our study, the discretionary loan loss provisions divided by total loans represent $-6.96 \mathrm{e}-12 \%$ with a maximum of $13.01 \%$.

The results show, also, that over the period of our study from 2001 to $2014,82.85 \%$ of the banks in our sample have an audit committee. In fact, despite the obligation to set up the audit committee within financial institutions under the 2001 law, only one bank (the ATB) introduced this body from 2001. The other banks introduced it later. In 2007, we find that all banks in our sample have an audit committee. This result is close to the one found by Marra et al (2011) on a sample of non-financial Italian firms with an average existence of this committee of $83.11 \%$ before IFRS and $80.45 \%$ after IFRS. The standard deviation of this variable is 37.82 , revealing its high volatility.

The accounting performance (return on assets) averages $0.78 \%$ with a maximum value of $3.1 \%$ and a minimum value of $(-8.8 \%)$. This allows us to note that the banks in our sample have a low performance on average. The standard deviation of this variable is $1.12 \%$, revealing its low volatility.

The size of the bank, as measured by the logarithm of total assets, shows an average of $14.98 \%$ with a standard deviation of $55.75 \%$, showing that the banks in our sample have a large dispersion in terms of regards the size.

The audit quality measured by the BIG has an average of $52.14 \%$, which indicates that about half of the banks in our sample use external auditors belonging to the BIG 4 group. The standard deviation of this variable is $50.13 \%$ revealing its high volatility.

Finally, the banks in our sample have an average age of 3.61 with a maximum of 4.04 and a minimum of 2.63.

\subsection{Regression Results}

The GLS estimation (corrected panel) presents the following results (see Table 2):

The examination of Table 2 allows us to advance the comments below. Contrary to what was expected, we find that there is a significant positive relationship at the $5 \%$ threshold between the presence of the audit committee and the discretionary provisions. This does not allow us to confirm our hypothesis. This indicates that the presence of a committee cannot constrain the discretionary behavior of managers of Tunisian commercial banks through loan loss provisions. This result suggests that one or all of the conditions of effectiveness of the audit committee is not fulfilled; and probably that members of audit committees in Tunisian banks lack the necessary accounting skills to obtain more reliable financial statements or that these committees do not perform the number of meetings sufficient (Chtourou \& Ben Hassine, 2006). Indeed, several recent research confirms that the effectiveness of the audit committee depends on its own characteristics (independence, expertise, size, activity) and not on its mere existence (Zgarni et al., 2018). The latter is therefore a necessary but insufficient condition 
for limiting the opportunistic behavior of managers.

Table 2. Regression of the effect of the presence of audit committee on discretionary provisions

\begin{tabular}{ccccccc}
\hline Variable & Coefficient & Standard error & $\mathrm{z}$ & $\mathrm{P}>|\mathrm{z}|$ & \multicolumn{2}{c}{$[95 \%$ Conf. Interval] } \\
\hline COM & .0123775 & .005116 & 2.42 & $0.016^{* *}$ & .0023504 & .0224046 \\
ROA & -.4856022 & $.1622359-$ & -2.99 & $0.003^{* * *}$ & -.8035787 & -.1676256 \\
LASSET & -.0241756 & $.0035214-$ & -6.87 & $0.000^{* * *}$ & -.0310775 & -.0172738 \\
BIG & -.0040256 & .0037554 & -1.07 & 0.284 & -.011386 & .0033349 \\
AGE & -.0109321 & .0061635 & -1.77 & $0.076^{*}$ & -.0230124 & .0011481 \\
Constante & .3975818 & .0521213 & 7.63 & 0.000 & .2954259 & .4997377 \\
\hline
\end{tabular}

COM: presence of audit committee; ROA: return on assets; LASSET: size of the bank; BIG: The belonging of the external auditor to the Big 4 group; AGE: age of the bank

$* * *$ significance at $1 \%, * *$ significance at of $5 \%$ and $*$ significance at $10 \%$

Our result is similar to that of Alves (2013), which finds that the presence of audit committee has a positive effect on the earnings management on a sample of non-financial companies in Portugal. Our results are also close to those of Peasnell et al. (2005) who have shown that there is no direct relationship between the presence of audit committee and the management of short-term results in the UK context. Carcello and Nagy (2004) do not validate, in their turn, the contribution of the mere existence of the audit committee to the quality of financial information disclosed. Peasnell et al. (2000) similarly showed that the presence of the audit committee does not limit the earnings management. It is rather its interaction with the composition of the board of directors that controls the discretionary behavior of the managers because the audit committees facilitate the supervisory role of the external directors of the board of directors by providing the necessary reports.

According to Alves (2013), there are at least three possible explanations for the positive relationship between the presence of the audit committee and the earnings management. The first is that members of the audit committee may be faced with a problem of information asymmetry, with less information on the elements they supervise than on management. The second is that members of the audit committee can be so inefficient, mainly because of multiple mandates and lack of knowledge that prevents them from understanding accounting information and if the accounting judgments made by managers are appropriate. A third possible explanation for this result may relate to the absence of effective audit committees in terms of independence, expertise, number of meetings and size. Indeed, several studies including those of Bukit and Iskandar, (2009), Chang and Sun (2009) and Sierra García et al. (2012) state that the independence of the audit committee constrains the earnings management. Other authors including, Dhaliwal et al. (2010) and Sierra García et al. (2012) show that the expertise of the audit committee plays an important role in limiting the earnings management. In addition, Saleh et al. (2007) showed that audit committee meetings reduce managerial discretion.

Our results differ from those found by Ahmed et al. (2013) who studied the effect of the audit committee and the board of directors on the earnings management in a sample of Nigerian and Malaysian banks over a period from 2007 to 2011 and which showed that this mechanism limits discretionary behavior of managers in these banks. These results are also opposed to those found by Ben Othman and Mersni (2016). Indeed, these authors confirm the role of the audit committee in limiting the discretionary behavior of managers in Islamic banks in the Middle East region. By the same token, we also disagree with the results of Sun et al. (2014), which prove that the audit committee plays a leading role in improving the quality of accounting information. This result is not also consistent with that of Beasley et al. (2000) on financial institutions.

We are also divergent from the results of studies by DeFond and Jiambalvo (1991) and McMullen (1996), showing that the presence of the audit committee plays an important role in improving the reliability of the disclosed financial information. Similarly, our result contradicts the one found by Dechow et al. (1996). Indeed, these authors have proved the fundamental role of the audit committee in limiting violations of accounting principles. McMullen (1996) and Uzun et al. (2004) also confirmed that the presence of the audit committee within companies is an effective fraud prevention mechanism that improves the quality of financial information disclosed.

These results also seem to contradict those found by Piot and Janin (2007) who showed that the audit committee' presence limits the upward earnings management in French companies. In this same context, Souid and Stepniewski (2010) proved that the presence of the audit committee limits the discretionary behavior of managers. This has also been demonstrated through the Davidson et al. (2005) in an Australian context. 
With respect to the relationship between the bank's accounting performance and discretionary provisions, we find a significant negative effect of this variable on discretionary provisions for Tunisian commercial banks. These results agree with the one found by Bhat (1996) who showed that the banks that manipulate their earnings perform poorly. The size of the bank seems to have a significant negative effect on the discretionary provisions in our sample. Regarding the of external audit quality measured by the auditor's membership in one of the BIG 4 networks, the results of the regression show the non-significant negative effect of this variable on the discretionary provisions in our sample. Regarding the age of the bank, this variable has a significant negative effect on managerial discretion.

\section{Conclusion}

This study aims was to determine the nature of the impact of the introduction of an audit committee on the financial reporting quality, in particular earnings management practices in the banking context. The results confirmed-that the audit committee' existence does not allow for a disciplinary role with respect to discretionary practices. The empirical results we have achieved, which are in the same vein as those reported by Alves (2013), show that the presence of the audit committee has a positive and significant effect on earnings management. This positive effect fails to approve the benefits of the audit committee. Unlike the agency theory, the audit committee' presence only reinforces the problem of earning management. This may be due to the fact that the audit committees of Tunisian banks do not respect the efficiency conditions recommended by the law.

A study of the impact of the various conditions of the audit committee' effectiveness, (Zgarni et al., 2018) particularly its expertise, on the earning management, could possibly bring us more in-depth conclusions. Finally, this present research does not lack limits. The main limitation refers to the small size of the sample. This calls for future comparative research between Tunisian banks and those of other developing countries.

\section{References}

Ahmed, A., \& Hassan, SH. U. (2013). Corporate Governance, Earnings Management and Financial Performance: A Case of Nigerian Manufacturing Firms. American International Journal of Contemporary Research, 2(7), 214-226.

Alves, S. (2013). The impact of audit committee existence and external audit on earnings management: Evidence from Portugal. Journal of Financial Reporting and Accounting, 11(2), 143-165. https://doi.org/10.1108/JFRA-04-2012-0018

Baxter. J., \& Cotter. P. (2009). Audit Committees and Earnings Quality. Working paper, 32 pages. https://doi.org/10.1111/j.1467-629X.2008.00290.x

Beasley, M. (1996). An empirical analysis of the relation between board of director composition and financial statement fraud. The Accounting Review, 71(2), 443-465. https://www.jstor.org/stable/248566

Beasley, M. S., Carcello, J. V., Hermanson, D. R., \& Lapides, P. D. (2000). Fraudulent Financial Reporting: Consideration of Industry Traits and Corporate Governance Mechanisms. Accounting Horizons, 14(4), 441-454. https://doi.org/10.2308/acch.2000.14.4.441

Ben Cheikh, S., \& Zarai, M. A. (2008). Importance des facteurs organisationnels sur le pouvoir managérial et la performance de la firme. Colloque international fiscalité droit gestion, 8, 9 et 10 Mai 2008.

Ben Othman, H., \& Mersni, H. (2016). The impact of corporate governance mechanisms on earnings management in Islamic banks in the Middle East region. Journal of Islamic Accounting and Business Research, 7(4), 318-348. https://doi.org/10.1108/JIABR-11-2014-0039

Brown, P. (2011). International Financial Reporting Standards: What are the benefits? Accounting and Business research, 41(3), 269-285. https://doi.org/10.1080/00014788.2011.569054

Bukit, R. B., \& Iskandar, T. M. (2009). Surplus free cash flow, earnings management and audit committee. Journal of Economics and Management, 3(1), 204-223.

Bushman, R. M., \& Smith, A. J. (2001). Financial accounting information and corporate governance. Journal of accounting and economy, 32, 237-333 https://doi.org/10.1016/S0165-4101(01)00027-1

Bushman, R. M., \& Smith, A. J. (2003). Transparency, Financial Accounting Information, and Corporate Governance. FRBNY Economic Policy Review, 65-87. https://doi.org/10.2139/ssrn.253302

Carassus, D., \& Cormier, D. (2003). L'évaluation du risque de fraude comme objet d'analyse de l'audit externe légal, Comptabilité, Contrôle, Audit, printemps.

Carcello, J. V., \& Nagy, A. L. (2004). Audit firm tenure and fraudulent financial reporting. Auditing: A Journal of 
Practice and Theory, 23, 55-69. https://doi.org/10.2308/aud.2004.23.2.55

Chang, J. C., \& Sun, H. L. (2009). Cross-listed foreign firms' earnings informativeness, earnings management and disclosures of corporate governance information under SOX. The International Journal of Accounting 44(1), 1-32. https://doi.org/10.1016/j.intacc.2008.12.004

Chen, et al. (2015). Does Increased Board Independence reduce earnings management? Evidence from recent regulatory reforms. Review of Accounting Studies, 20(2), 899-933. https://doi.org/10.1007/s11142-015-9316-0

Chtourou, M. S., \& Ben Hassine, S. (2006). Impact de la mise en places des comités d'audit dans les banques tunisiennes. https://www.halshs.archives-ouvertes.fr/halshs-00548104.

Davidson, R., Goodwin-Stewart, J., \& Kent, P. (2005). Internal governance structures and earning management. Accounting and Finance, 45, 241-267. https://doi.org/10.1111/j.1467-629x.2004.00132.x

Dechow, P., Sloan, R., \& Sweeney, A. P. (1996). Causes and consequences of earnings manipulation: An Analysis of Firms Subject to Enforcement Actions by the SEC. Contemporary accounting research, 13, 1-36. https://doi.org/10.1111/j.1911-3846.1996.tb00489.x

DeFond, M. L., \& Jiambalvo, J. (1991). Incidence and Circumstances of Accounting Errors. The Accounting Review, 66(3), 643-655. https://www.jstor.org/stable/247814

Dhaliwal, D., Naiker, V., \& Navissi, F. (2010). The association between accruals quality and the characteristics of accounting experts and mix of expertise on audit committees. Contemporary Accounting Research, 27(3), 787-827. https://doi.org/10.1111/j.1911-3846.2010.01027.x

Jaggi, B., \& Leung, S. (2007). Impact of family dominance on monitoring of earnings management by audit management: Evidence from Hong Kong. Journal of International Accounting, Auditing and Taxation, 16(1), 27-50. https://doi.org/10.1016/j.intaccaudtax.2007.01.003

Janin, R., \& Piot, C. (2008). L'influence des auditeurs externes et des comités d'audit sur le contenu informative des manipulations comptables. La Revues des Sciences de gestion, 5(233), 2333. https://doi.org/10.3917/rsg.233.0023

Kanagaretnam, K., Lobo, G. J., \& Mathieu, R. (2004). Earnings Management to Reduce Earnings Variability: Evidence from Bank Loan Loss Provisions. Review of Accounting and Finance, 3(1), 128-148. https://doi.org/10.1108/eb043399

Kothari, S. P., Leone, A. J., \& Wasley, C. E. (2005). Performance matched discretionary accrual measures. Journal of Accounting \& Economics, 39(1), 163-197. https://doi.org/10.1016/j.jacceco.2004.11.002

Leventis, S., \& Dimitropoulos, P. (2011). Loan loss provisions, earnings management under IFRS: The case of EU commercial banks. Journal of Financial Services Research, 40(1-2), 103-122. https://doi.org/10.1007/s10693-010-0096-1

Macey, J. R., \& Maureen, O. (2003). The corporate governance of banks. Economic Policy Review, 9(1Special Issue), 91-108. https://ssrn.com/abstract=795548

Marra, A., Mazzola, P., \& Prencipe, A. (2011). Board monitoring and earnings management pre- and post-IFRS. The International Journal of Accounting, 46, 205-230. https://doi.org/10.1016/j.intacc.2011.04.007

McMullen, D., \& Raghunandan, A. (1996). Enhancing audit committee effectiveness. Journal of Accountancy, 182(August), 79-81.

Peasnell, K. V., Pope, P. F., \& Young, S. (2005). Board monitoring and earnings management: Do outside directors influence abnormal accruals. Journal of business Finance Accounting, 32(7-8), 1311-1346. https://doi.org/10.1111/j.0306-686X.2005.00630.x

Peasnell, K., Pope, P., \& Young, S. (2000). Accrual Management to Meet Earnings Targets: UK Evidence Preand Post-Cadbury. The British Accounting Review, 32(4), 415-445. https://doi.org/10.1006/bare.2000.0134

Piot, C., \& Janin, R. (2007). External Auditors, Audit Committees and Earnings Management in France. European Accounting Review, 16(2), 429-454. https://doi.org/10.1080/09638180701391030

Piot, C., \& Kermiche, L. (2009). A quoi servent les comités d'audit? Un regard sur la recherche empirique, Comptabilité - Contrôle - Audit 2009/3 (Tome 15) Pages: 176. 60 pages. Éditeur: Association francophone de comptabilité. https://doi.org/10.3917/cca.153.0009

Pittman, J. A., \& Fortin, S. (2004). Auditor choice and the cost of debt capital for newly public firms. Journal of 
accounting and economics, 37, 113-136. https://doi.org/10.1016/j.jacceco.2003.06.005

Sierra García, L., Ruiz Barbadillo, E., \& Orta Pérez, M. (2012). Audit committee and internal audit and the quality of earnings: empirical evidence from Spanish companies. Journal of Management \& Governance, 16(2), 305-331. https://doi.org/10.1007/s10997-010-9152-3

Smith, R. (2003). Audit committee combined code guidance: A report and proposed guidance by an FRC-appointed group. London: Financial Reporting Council. Retrieved from http://www.frc.org.uk/publications

Souid, S., \& Stepniewski, Y. (2010). Rôle du conseil d'administration et gestion des résultats. La Revue des Sciences de Gestion, 3(243-244), 35-41. https://doi.org/10.3917/rsg.243.0035

Sun, J., Lan, L., \& Liu, G. (2014). Independent audit committee characteristics and real earnings management. Managerial Auditing Journal, 29(2), 153-172. https://doi.org/10.1108/MAJ-05-2013-0865

Uzun, H., Szewczyk, S. H., \& Varma, R. (2004). Board composition and corporate fraud. Financial Analyst Journal, 60(3), 33-43. https://doi.org/10.2469/faj.v60.n3.2619

Watts, R. L., \& Zimmerman, J. L. (1986). Positive accounting theory. Prentice-Hall. https://ssrn.com/abstract=928677

Watts, R. L., \& Zimmerman, J. L. (1990). Positive Accounting Theory: A Ten Year Perspective. The Accounting Review, 65(1), 131-156. https://www.jstor.org/stable/247880

Zgarni, A., Fedhila, H., \& El Gaied, M. (2018). Audit Committee and Discretionary Loan Loss Provisions in Tunisian Commercial Banks. International Journal of Economics and Financial Issues, 8(2), 85-93. Retrieved from http://www.econjournals.com

\section{Copyrights}

Copyright for this article is retained by the author(s), with first publication rights granted to the journal.

This is an open-access article distributed under the terms and conditions of the Creative Commons Attribution license (http://creativecommons.org/licenses/by/4.0/). 